\title{
The Use of Woodland Lichen Pasture by Reindeer in Winter with Easy Snow Conditions
}

\author{
JOUKO KUMPULA, ${ }^{1,2}$ STÉPHANIE C. LEFRÈRE ${ }^{3}$ and MAURI NIEMINEN ${ }^{1}$
}

(Received 28 February 2003; accepted in revised form 29 January 2004)

\begin{abstract}
Our aim was to investigate the amount of digging work (cratering) done by semi-domesticated reindeer (Rangifer t. tarandus) in woodland lichen pasture and the effect of snow and pasture conditions on the body condition of female reindeer. From 17 February until 21 April 2001, eight barren reindeer females were allowed to graze freely in a fenced area (20 ha). Measurements before the study showed the amount of lichens within the fenced area to average $632 \mathrm{~kg} \mathrm{DM} / \mathrm{ha}$ in dry pine forest. Inside the fenced area, there was $31.1 \mathrm{~cm}$ of relatively soft snow in February and $41.8 \mathrm{~cm}$ in April. Observations showed that in February the reindeer spent $39.8 \%$ of the time digging and grazing and $1.0 \%$ foraging arboreal lichens. In April, they spent $29.8 \%$ of the time digging and grazing and 5.2\% foraging arboreal lichens. During cratering, reindeer foraged (dug and picked food) with a certain repeated rhythm, using both front feet equally. The size of the grazed area and the volume of snow removed from a single crater were dependent on the total foraging time per crater. The mean body mass of the reindeer was $67.1 \pm 2.67 \mathrm{~kg}$ in mid-February and $64.9 \pm 2.98 \mathrm{~kg}$ in late April. It was calculated that in February one reindeer dug and grazed $75.6 \mathrm{~m}^{2}$ per day, and the mean change in reindeer body mass was actually $+39 \mathrm{~g}$ per day. In April the corresponding figures for one reindeer were $60.1 \mathrm{~m}^{2}$ and $-27 \mathrm{~g}$ per day. In the snow and pasture conditions prevailing during this study, the reindeer were able to get enough food and thereby energy to preserve their body condition well.
\end{abstract}

Key words: reindeer, cratering, grazing, digging, foraging, body condition, snow conditions, lichens, pasture

RÉSUMÉ. Notre but était de déterminer l'importance du creusage (fouissage) effectué par le renne semi-domestique (Rangifer t. tarandus) dans les pâturages de lichen forestier, ainsi que les répercussions des conditions de la neige et du pâturage sur l'état corporel du renne femelle. Du 17 février au 21 avril 2001, on a laissé huit rennes femelles non gravides brouter à leur guise dans un emplacement clôturé (20 ha). Des mesures effectuées avant le début de l'étude montraient que la quantité de lichens dans la zone clôturée était en moyenne de $632 \mathrm{~kg} / \mathrm{ha}$ de matière sèche dans la pinède sèche. À l'intérieur de la zone clôturée, il y avait $31,1 \mathrm{~cm}$ de neige relativement molle en février et $41,8 \mathrm{~cm}$ en avril. Les observations ont révélé qu'en février les rennes ont passé $39,8 \%$ du temps à creuser et à brouter et $1,0 \%$ en quête de lichens corticoles. En avril, ils ont passé $29,8 \%$ du temps à creuser et à brouter, et 5,2\% à se nourrir de lichens corticoles. Durant le fouissage, les rennes s'alimentaient (creusaient puis prenaient la nourriture) selon un mode répétitif, se servant autant d'une patte antérieure que de l'autre. La taille de la zone broutée et le volume de la neige enlevée à un seul site de fouissage dépendaient du temps total passé à rechercher la nourriture à ce site. La moyenne de la masse corporelle du renne était de $67,1 \pm 2,67 \mathrm{~kg}$ à la mi-février et de $64,9 \pm 2,98 \mathrm{~kg}$ à la fin avril. On a calculé qu'en février un renne a creusé et brouté $75,6 \mathrm{~m}^{2}$ par jour, et que la moyenne du changement de la masse corporelle du renne était en fait de $+39 \mathrm{~g}$ par jour. En avril, les chiffres correspondants pour un renne étaient de $60,1 \mathrm{~m}^{2}$ et de $-27 \mathrm{~g}$ par jour. Dans les conditions de neige et de pâturage qui prédominaient durant l'étude, le renne était capable de se procurer suffisamment de nourriture - et donc d'énergie - pour conserver un bon état de santé.

Mots clés: renne, fouissage, broutage, creusage, recherche de nourriture, état corporel, conditions de neige, lichens, pâturage

Traduit pour la revue Arctic par Nésida Loyer.

\section{INTRODUCTION}

Although caribou and reindeer expend one-third less total energy in winter than in summer, some winter activities nevertheless consume a lot of energy (Boertje, 1985; Adamczewski et al., 1993). Digging through a hard, compacted snow layer can demand over four times as much energy per stroke as digging through soft snow (Fancy and
White, 1985). Locomotion in soft snow also increases energy expenditure (Fancy and White, 1987). Nevertheless, the body structure and digging technique of reindeer and caribou have both evolved to help save energy (Thing, 1977; Fancy and White, 1985). In particular, the size and structure of the front feet facilitate effective and fast sweeping of snow from a crater (Thing, 1977).

\footnotetext{
${ }^{1}$ Finnish Game and Fisheries Research Institute, Reindeer Research Station, FIN-99910 Kaamanen, Finland

${ }^{2}$ Corresponding author: jouko.kumpula@ rktl.fi

${ }^{3}$ René Descartes University, Animal and Human Ethology Department (Paris V)-12, rue de l’Ecole de Médecine, 75270 Paris Cedex 06

(C) The Arctic Institute of North America
} 
Body reserves can supply only $15-20 \%$ of the caribou's energy requirements in winter (Adamczewski et al., 1993). The remaining energy requirements of both reindeer and caribou are obtained from their forage. The amount and structure of snow affect foraging behaviour of reindeer and caribou (Skogland, 1978; Helle, 1979; Rominger et al., 1996; Kumpula, 2001). In winter, when the snow is soft and shallow, they both forage terrestrial lichens (Cladonia spp.) and other terrestrial plants such as sedges, dwarf shrubs, and grasses. When the snow is hard and deep, they may shift their preference to arboreal lichens (Alectoria spp., Bryoria spp.) depending on availability (Helle, 1979; Helle and Tarvainen, 1984; Johnson et al., 2000, 2001; Poole et al., 2000). The smaller the supply of Cladonia lichens in pasture, the easier the snow conditions that cause reindeer to shift their diet to arboreal lichens (Helle and Tarvainen, 1984). For many caribou, however, foraging for terrestrial or arboreal lichens does not represent their choice between alternative food sources: they simply have to use what is available. For example, some northern caribou populations forage terrestrial lichens when in alpine areas, but when in forests, they almost certainly feed on arboreal lichens (Poole et al., 2000).

When feeding in hard snow, reindeer and caribou usually prefer the shallowest places to dig (Adamczewski et al., 1988; Collins and Smith, 1991; Larter and Nagy, 2001). In late winter, reindeer also prefer rugged terrain types (Nellemann, 1996) since such areas have lesser snow accumulation and removing snow from a crater is easier on a ridge than in a flat area. However, if there are enough lichens and other food plants, reindeer will also dig in hard, deep snow (Helle, 1984).

Although digging work (cratering) is an essential part of reindeer foraging behaviour in winter, relatively few studies have been made on the subject. In this work, one of our interests was to show how much digging work reindeer have to do under various pasture and snow conditions. We also monitored the effects of snow and pasture conditions on the body condition of reindeer. These questions could also be important for practical reindeer herding, for example, when estimating the area of pasture required per reindeer.

\section{MATERIAL AND METHODS}

From 17 February until 21 April 2001, eight barren female reindeer were allowed to graze freely in the fenced area (20 ha) of the reindeer research station in the Finnish Game and Fisheries Research Institute in Kaamanen, Lapland. The fenced area comprised two-thirds dry pine forest and one-third submesic pine forest and mire. Barren females were selected for the study because the total body mass changes of nonpregnant females better represent changes in the real body condition than do those of pregnant females, whose body mass change in winter is complicated by the development of the foetus. Before the study, the pregnancy status of females was checked by ultrasonic camera.
The reindeer research station $\left(69^{\circ} 03^{\prime} 50^{\prime \prime} \mathrm{N}, 27^{\circ} 06^{\prime}\right.$ $36^{\prime \prime} \mathrm{E}$ ) is located in the northern boreal zone of Europe, and dry pine forests characterize the area. The terrain near the research station is $145-160 \mathrm{~m}$ above sea level. The coldest month is January (average temperature $-14.3^{\circ} \mathrm{C}$ ) and the warmest one July (average temperature $+13.7^{\circ} \mathrm{C}$ ). In March there is about $67 \mathrm{~cm}$ of snow (Finnish Meteorological Institute, 2003a, b, c). The early winter of 2000-01 was relatively mild, with exceptionally little snow in December: only $20 \mathrm{~cm}$ in the study area. The midwinter period was a little colder than usual, but there was still only $55 \mathrm{~cm}$ of snow in March, when there is usually at least $65 \mathrm{~cm}$. The late winter was mild again, with little snowfall (Finnish Meteorological Institute, 2000, 2001a, b).

An average amount of lichens in dry pine forest in the previous autumn was estimated on the basis of 470 vegetation squares. First, 30 stakes were randomly placed in dry pine forest. At a distance of $2 \mathrm{~m}$ from each stake, we marked the centres of four vegetation squares (size $0.25 \mathrm{~m}^{2}$ ) at the four main compass points. However, if a square contained any large rocks, trees or tree stumps, it was not used in the study. In each square, we estimated the average coverage and height of the lichen stand formed by the four most important lichens (Cladina stellaris, $C$. mitis, C. rangiferina, and Cladonia uncialis). The dry matter biomass of lichens in each square was then calculated on the basis of their coverage and height, using the formula of Kumpula et al. (2000).

Digging work, foraging, and activity of reindeer were studied in two separate periods, 17-28 February and 2-21 April 2001. (Between these periods reindeer were also allowed to graze freely on pasture.) These observation periods covered all daylight hours from dawn to dusk, about 8 hours in February and 15 hours 30 minutes in April. Activity of reindeer was scanned by selecting an individual reindeer at random for detailed observation over a 15-minute period (sometimes a 15-minute scanning period was not filled because the scanned reindeer was lost in the forest). During each 15-minute period, the behaviour of the individual was recorded every 15 seconds. Total scanning time was 21 hours 25 minutes in February (during 9 days) and 31 hours 52 minutes in April (during 6 days). Thus the study reindeer were scanned for 17.8 minutes per daylight hour in February and 20.6 minutes per daylight hour in April. This difference resulted from harsh weather conditions in February (sometimes temperatures fell under $-35^{\circ} \mathrm{C}$ ), which made fieldwork more difficult than in April. However, it probably has little effect on the results. The cratering of reindeer was also measured and observed separately during both observation periods. After opening a crater, the reindeer dug in a certain cyclic rhythm, repeatedly alternating between pawing and picking food from the crater. For each foraging cycle, we measured the length of time (from start point of pawing to end point of food picking), counted the number of pawings, and identified the front foot used in the digging work. 
When a reindeer was seen to start opening a new crater, the total time of making and grazing this single crater was measured. This was done 19 times in February and 16 times in April. Width, length, and depth of the grazing area in each crater were measured and the size of the grazed area calculated. The body mass of each reindeer was recorded at the beginning and end of both grazing periods. In addition, at the beginning of each grazing period, snow depth $(\mathrm{cm})$, snow density $\left(\mathrm{g} / \mathrm{dm}^{2}\right)$, and hardness $\left(\mathrm{g} / \mathrm{cm}^{2}\right)$ of the hardest snow layer on the pasture were measured using special instruments.

In order to carry out these measurements, we marked 16 snow measurement sites at $20 \mathrm{~m}$ intervals along a straight line through the middle of the dry pine forest inside the fenced area. For density measurements, a tube with a diameter of $10.1 \mathrm{~cm}$ was pushed vertically through the whole snow layer and a core of snow was removed. The weight and height of this snow core were then measured and its volume was calculated. The density of each snow sample was then calculated from its volume and weight. To measure snow hardness, we used a special instrument with round flappers of different sizes and a spring for measuring the force against a certain flapper that is pushed against a snow layer. The vertical hardness $\left(\mathrm{g} / \mathrm{cm}^{2}\right)$ of the hardest snow layer in the snowpack was calculated on the basis of the size of the flapper used and the force needed to break the layer.

The t-test was used to analyze differences in several variables between the two grazing periods. The difference in body mass of female reindeer between the beginning and end of the grazing experiment was analyzed by the paired t-test. Differences in the distribution of activity percentages between the two grazing periods were analyzed by the chi-square test. The chi-square test was also used to see if the reindeer preferred to use one or the other front foot for digging. Finally, we analyzed the dependence of grazing area and snow volume removed from a crater on total foraging time (digging and grazing) used per crater, using the nonlinear regression model.

On the basis of these results, we estimated the total digging and grazing area per reindeer per 24 hours. We had to assume that reindeer dug and rested during the dark period in the same way as they did in daylight. This assumption may not be fully correct, but it is based on the fact that the dark period in midwinter is very long, and coldness probably forces reindeer to follow nearly the same foraging rhythm during the whole 24 hours as they do in daylight. In April, on the contrary, the dark period is much shorter and may not affect the total daily foraging rhythm very much. However, first we calculated the total digging and grazing time per 24 hours as a percentage of daytime activity in both of the grazing periods. Second, we calculated the time used to dig and graze an average crater from the dependency found between digging and grazing time and crater size. Then we divided the total digging and grazing time per 24 hours by the time needed to dig and graze one average crater in each period. To calculate the total area cratered by one reindeer in 24 hours in each period, we multiplied this figure by the average crater size in that period.

\section{RESULTS}

Measurements showed that the snow conditions were relatively easy for the reindeer throughout the 2000-01 winter, although significantly more difficult in April than in February. Average snow depth on the lichen pasture inside the fence was $31.1 \mathrm{~cm}(\mathrm{SD}=3.97, n=16)$ in midFebruary and $41.8 \mathrm{~cm}(\mathrm{SD}=6.29, n=16)$ in early April $(\mathrm{t}=-5.80, \mathrm{df}=25.3, p<0.001)$. Average snow density was $159 \mathrm{~g} / \mathrm{dm}^{2}$ (SD $\left.=20.8, n=16\right)$ in mid-February and $239 \mathrm{~g} / \mathrm{dm}^{2}(\mathrm{SD}=21.3, n=16)$ in early April $(\mathrm{t}=-10.76$, $\mathrm{df}=30, p<0.001)$. Snow hardness in the hardest snow layer was $1062 \mathrm{~g} / \mathrm{cm}^{2}(\mathrm{SD}=503.2, n=16)$ in mid-February and $1519 \mathrm{~g} / \mathrm{cm}^{2}(\mathrm{SD}=791.6)$ in early April $(\mathrm{t}=-1.95$, $\mathrm{df}=25.4, p=0.063)$.

The daytime activity of reindeer varied significantly between February and April $\left(\chi^{2}=13.44, \mathrm{df}=4, p<0.01\right)$. In February, reindeer spent more time digging and grazing than in April (Fig. 1). In April, lying down was the most common activity, and reindeer also foraged on arboreal lichens more than in February. On the basis of vegetation squares, we calculated an average of $15.8 \pm 0.54 \mathrm{~g} \mathrm{DM} /$ $0.25 \mathrm{~m}^{2}$ of lichen in the lichen pasture inside the fenced area before the study. This means that there was an average of $632 \mathrm{~kg} \mathrm{DM} / \mathrm{ha}$ of lichen in this pasture.

During the actual cratering period and after opening a crater, reindeer foraged (dug and picked food) in a certain repeated rhythm, the total length of which was on average $30.2 \mathrm{~s}(\mathrm{SD}=15.95, n=257)$ in February and $35.9 \mathrm{~s}(\mathrm{SD}=$ $22.31, n=145)$ in April $(\mathrm{t}=-2.71, \mathrm{df}=228.3, p<0.01)$. In February, a rhythm comprised an average of 6.8 pawing movements and a 21.5 second period for food picking. In April, a rhythm comprised an average of 9.5 pawing movements and a 29.4 second period for food picking. The average speed of pawing was 1.5 pawings per second (SD $=0.35, n=229)$ in February and 1.7 pawings per second $(\mathrm{SD}=0.38, n=146)$ in April $(\mathrm{t}=-3.13, \mathrm{df}=288.7$, $p<0.01)$. When digging, reindeer used both front feet equally (218 cases of right foot and 214 cases of left foot, $\left.\chi^{2}=0.037, \mathrm{df}=1, p=0.847\right)$.

The average size of the grazed area within a crater was $1.51 \mathrm{~m}^{2}(\mathrm{SD}=0.47, n=19)$ in February (mean snow depth in crater $38.3 \mathrm{~cm})$ and $1.40 \mathrm{~m}^{2}(\mathrm{SD}=0.94, n=16)$ in April (mean snow depth in crater $44.3 \mathrm{~cm})(\mathrm{t}=0.414, \mathrm{df}=21.1$, $p=0.683)$. The average amount of snow reindeer had to remove from a single crater was $0.578 \mathrm{~m}^{2}$ in February and $0.620 \mathrm{~m}^{2}$ in April. Size of the grazed area $\left(\mathrm{m}^{2}\right)$ within a crater was dependent on the length of time (seconds) that a reindeer used a crater $\left(\mathrm{R}^{2}=0.51, \mathrm{y}=-0.008 \mathrm{x}+0.0196 \mathrm{x}^{0,9}\right.$, $n=35, p<0.001$, Fig 2 ), as was the volume of snow removed $\left(\mathrm{R}^{2}=0.39, \mathrm{y}=-3.505 \mathrm{x}+8.447 \mathrm{x}^{0,9}, n=35\right.$, $p<0.001$, Fig 3). 


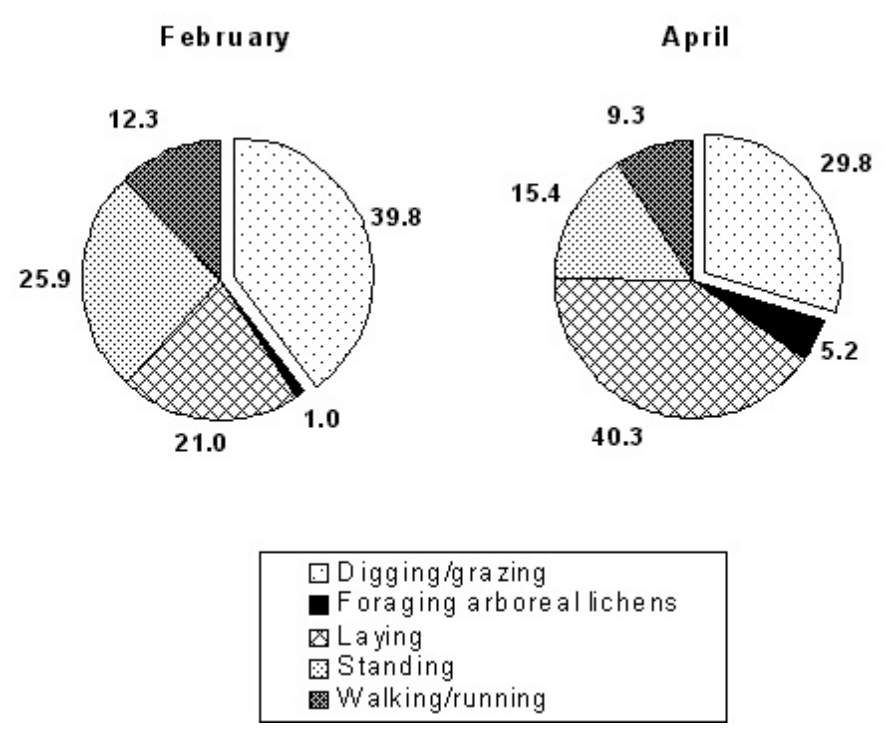

FIG. 1. Percentage of time reindeer spent on various activities during the two study periods.

The mean body mass of reindeer was $67.1 \pm 2.67 \mathrm{~kg}$ in mid-February and $64.9 \pm 2.98 \mathrm{~kg}$ at the end of April $(\mathrm{t}=2.049, n=8, p=0.08)$. The average measured weight change of reindeer was $+39 \mathrm{~g} /$ day $(\mathrm{SD}=0.198 ; n=8)$ during the February observation period and $-27 \mathrm{~g} /$ day ( $\mathrm{SD}=0.065, n=8)$ during the April observation period, although the difference in weight change between the periods was not statistically significant $(\mathrm{t}=0.901, \mathrm{df}=8.5$, $p=0.393$ ). If the reindeer had foraged in the same way during the whole 24 hours as observed in the daylight time, one reindeer would have dug and grazed about $75.6 \mathrm{~m}^{2} / 24 \mathrm{~h}$ in February and about $60.1 \mathrm{~m}^{2} / 24 \mathrm{~h}$ in April.

\section{DISCUSSION}

Compared with a normal winter, the winter of 2000-01 had little snow. The snow depth in the study area was just over $30 \mathrm{~cm}$ in early February and a little over $40 \mathrm{~cm}$ in early April, compared to $60 \mathrm{~cm}$ in February and $65 \mathrm{~cm}$ in April during an average winter (Finnish Meteorological Institute, 2003a, c). The snow was not compressed, although there was one hard snow layer in the snowpack during winter. Consequently the reindeer could get their food quite easily: they used only $39.8 \%$ of the total time in February and $29.8 \%$ in April in cratering and grazing, which is less than reported in some previous studies of reindeer (Helle, 1984; Collins and Smith, 1991) or caribou (Russell and Martell, 1984). The total weight loss of reindeer in the whole study period was also only $3.3 \%$, which is a relatively small change compared to normal body mass loss observed in reindeer (Nieminen and Petersson, 1990) or caribou (Adamczewski et al., 1993) in winter.

In February, reindeer spent $40.8 \%$ of the total daytime in all foraging activities (cratering/grazing and foraging arboreal lichens) and $21.0 \%$ in lying down. In April, on the

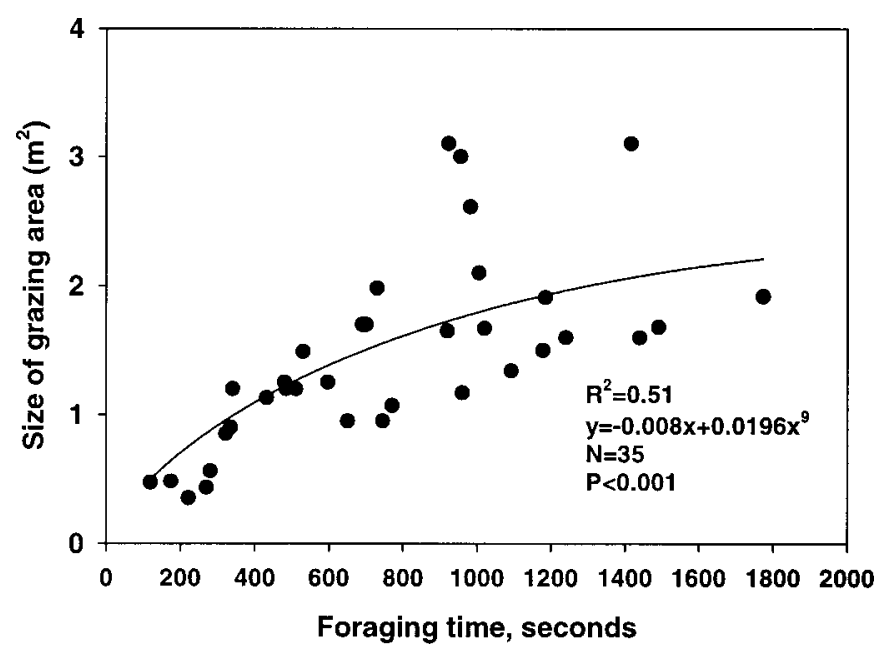

FIG. 2. Dependence of grazing area on total foraging time (digging and grazing) used per crater.

contrary, reindeer spent $35.0 \%$ of the total daytime in all foraging activities and $40.3 \%$ in lying down. The same kind of change in activity pattern from midwinter to late winter was observed, at least in caribou, in some earlier studies (Roby, 1978, 1980; Russell and Martell, 1980). This change in activity may depend on the differences in weather coldness and daylight length between midwinter and late winter. In late winter, when temperature is mild and the daylight time is very long, reindeer and caribou use less time in foraging and more time in lying down than in midwinter.

However, with difficult snow and digging conditions in late winter, reindeer have been observed to spend as much, or even more, time in foraging than in midwinter (Gaare et al., 1975; Helle, 1984). Probably much longer daylight time, relatively mild weather, and easy snow conditions in April also allowed our reindeer to rest most of the time instead of foraging. Reindeer could also save energy by lying down. Svalbard reindeer can spend up to $45 \%$ of their time lying down in winter and in this way conserve the equivalent of about 15 days' energy requirement over the winter (Cuyler and Øritsland, 1993). The reindeer in our study used only $5 \%$ of the total time in foraging on arboreal lichens in April, which also suggests that getting food by cratering satisfied their energy requirements well. In the previous study (Kumpula, 2001) made in the same fenced area, reindeer were seen to stop cratering and start foraging arboreal lichens in April, when the snow was over $80 \mathrm{~cm}$ deep and contained some hard layers.

While cratering, the reindeer showed a certain repeated rhythm, which grew longer as snow conditions made digging more difficult. Reindeer also spent more time in food picking in April than in February. It is obvious that removing snow from a crater takes longer when snow conditions turn more difficult. Thus, the amount of energy spent cratering is essentially dependent on snow conditions (Thing, 1977; Fancy and White, 1985). To compensate for the energy costs of digging as the snow conditions 


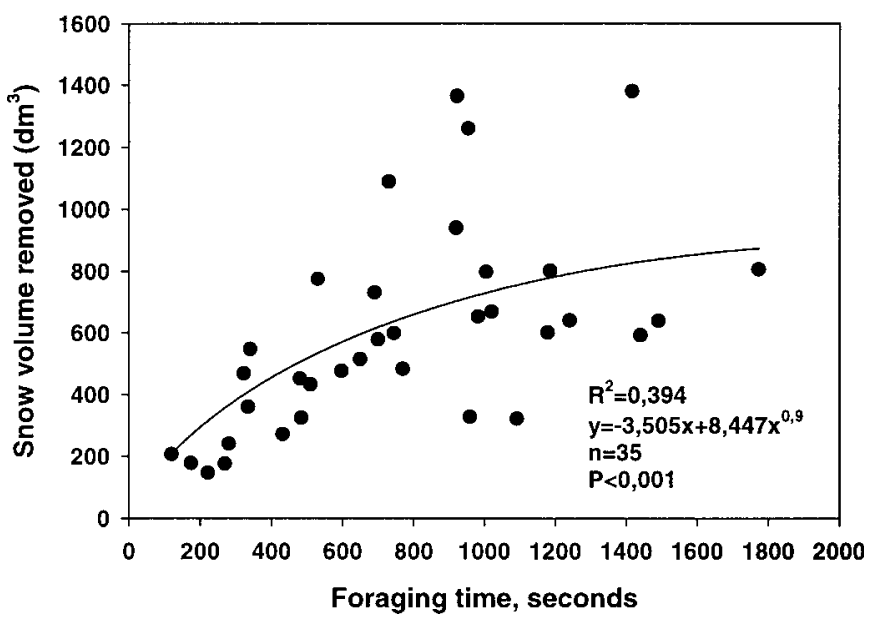

FIG. 3. Dependence of snow volume removed from a crater on total foraging time (digging and grazing) used per crater.

become more difficult, reindeer have to use lichens and other plants in a crater more effectively (Helle, 1984).

Although our study did not identify the type of pawing, as Thing (1977) recorded it for caribou, our reindeer probably used a slow pawing movement because the speed of pawing was clearly lower than that observed by Thing. Reindeer in our study grazed in deeper but softer snow than the caribou in Thing's (1977) study, which may explain why their pawing movements were slower. In our study, reindeer also used both front feet equally in cratering, whereas Thing's (1977) caribou used the right front foot more frequently than the left one when cratering. In hard, thin snow, reindeer and caribou probably use their right front foot more than the left one if the right foot is stronger than the left. However, it seems reasonable for reindeer or caribou to use both front feet equally because it makes cratering more effective. Also, they don't have to change position so often during cratering when both front feet can be used in the same way.

The crater size did not differ between study periods, probably because of the easy snow conditions in both periods. When the snow is deep and hard, reindeer usually dig very long, canal-like hollows (Helle, 1984; Kumpula, 2001). The reindeer in our study did not have to dig in this kind of snow condition.

The longer the reindeer foraged in a crater, the more slowly they removed snow and increased the grazing area in the crater. This is understandable since reindeer first removed snow from a crater rapidly, after which they concentrated more on feeding and expanded the crater more slowly. The reindeer still maintained a certain rhythm in digging and foraging, the length of which depended on the snow conditions. The digging work of the reindeer was relatively fast: it took a little over 11 minutes to dig and graze an average crater of the size $1.5 \mathrm{~m}^{2}$ in February. It is obvious that under more difficult snow conditions, the speed of digging and grazing would have been much slower.
Because the reindeer females in this study were barren, changes in body mass showed the changes in body condition well. If each reindeer dug and grazed the estimated $75.6 \mathrm{~m}^{2}$ per day in February and $60.1 \mathrm{~m}^{2}$ per day in April, and consumed half of the lichens in the average grazing area $\left(31.6 \mathrm{~g} \mathrm{DM} / \mathrm{m}^{2}\right)$, her lichen intake would have been around $2.389 \mathrm{~kg} \mathrm{DM} /$ day in February and $1.899 \mathrm{~kg} \mathrm{DM} /$ day in April. Because the metabolizable energy content of lichens is around $10.8 \mathrm{MJ} / \mathrm{kg} \mathrm{DM}$ (see Isotalo, 1974; Salo et al., 1982; Nieminen and Heiskari, 1989), each reindeer's daily consumption would yield $25.8 \mathrm{MJ}$ in February and 20.5 MJ in April of metabolizable energy from lichens.

In relatively good pasture conditions in winter for caribou and reindeer, $50-80 \%$ of all food utilized are usually lichens (Scotter, 1967; Miller, 1974; Russell and Martell, 1984; Kojola et al., 1995). The metabolizable energy requirement of reindeer and caribou females in winter, when the metabolic rate decreases and the fat catabolism increases, has been estimated to vary between 20.5 and 23.7 MJ per day and per animal (McEwan and Whitehead, 1970; Boertje, 1985). Our calculations and figures show that in the snow and pasture conditions prevailing in this study, the reindeer were able to get enough food and thereby energy to maintain their body condition well. In particular, the amounts of terrestrial lichens $(632 \mathrm{~kg} / \mathrm{ha})$ in these snow conditions supported the reindeer energy budget well. However, had the reindeer females been pregnant and snow conditions more difficult, the reindeer would probably have lost more of their body condition. Therefore, the combination of snow and pasture conditions essentially affects how well reindeer or caribou are able to maintain their body condition at a sufficient level through the winter.

\section{ACKNOWLEDGEMENTS}

We thank Jukka Siirari and Heikki Törmänen from the Reindeer Research Station for helping to collect and handle data. We also thank the Reindeer Herders' Association for allowing us to use their reindeer in this study. Finally, we thank Carola Eklundh for checking the language of the manuscript.

\section{REFERENCES}

ADAMCZEWSKI, J.Z., GATES, C.C., SOUTAR, B.M., and HUDSON, R.J. 1988. Limiting effect of snow on seasonal habitat use and diets of caribou (Rangifer tarandus groenlandicus) on Coats Island, Northwest Territories, Canada. Canadian Journal of Zoology 66:1986-1996.

ADAMCZEWSKI, J.Z., HUDSON, R.J., and GATES, C.C. 1993. Winter energy balance and activity of female caribou on Coats Island, Northwest Territories: The relative importance of foraging and body reserves. Canadian Journal of Zoology 71:1221-1229. 
BOERTJE, R.D. 1985. An energy model for adult female caribou of the Denali herd, Alaska. Journal of Range Management 38:468-473.

COLLINS, W.B., and SMITH, T.S. 1991. Effects of wind-hardened snow on foraging by reindeer (Rangifer tarandus). Arctic 44(3):217-222.

CUYLER, L.C., and ØRITSLAND, N.A. 1993. Metabolic strategies for winter survival by Svalbard reindeer. Canadian Journal of Zoology 71:1787-1792.

FANCY, S.G., and WHITE, R.G. 1985. Energy expenditures by caribou while cratering in snow. Journal of Wildlife Management 49:987-993.

1987. Energy expenditures for locomotion by barrenground caribou. Canadian Journal of Zoology 65:122-128.

FINNISH METEOROLOGICAL INSTITUTE. 2000. Weather report, December 2000. 11 p.

2001a. Weather report, March 2001. 11 p.

2001b. Weather report, April 2001. 11 p.

2003a. Weather report, February 2003. 11 p.

2003b. Weather report, March 2003. 11 p.

2003c. Weather report, April 2003. 11 p.

GAARE, E., THOMSON, B.R., and KJOS-HANSSEN, O. 1975. Reindeer activity on Hardangervidda. In: Wielgolaski, F.E., ed. Fennoscandian tundra ecosystems. New York: Springer-Verlag. 206-215.

HELLE, T. 1979. Lumipeite porojen laidunnuksen säätelijänä Kuusamossa (The role of snow in feeding behaviour of semidomestic reindeer in Kuusamo, northeastern Finland). In Finnish with English abstract. In: Viramo, J., ed. Studies on the natural environment of the Kuusamo district, northeastern Finland. Proceedings of a symposium held at Oulanka, 7-9 March 1977. Oulun yliopiston. Acta Universitatis Ouluensis, Series A, No. 68. 129-134.

- 1984. Foraging behaviour of the semi-domestic reindeer (Rangifer tarandus L.) in relation to snow in Finnish Lapland. Report of the Kevo Subarctic Research Station 19:35-47.

HELLE, T., and TARVAINEN, L. 1984. Determination of the winter digging period of semi-domestic reindeer in relation to snow conditions and food resources. Report of the Kevo Subarctic Research Station 19:49-56.

ISOTALO, A. 1974. Porojen luonnonvaraisten rehujen ravintoarvoista (The value of the natural fodder plants on reindeer feeding). In Finnish. Lapin tutkimusseuran vuosikirja 12: $28-45$.

JOHNSON, C.J., PARKER, K.L., and HEARD, D.C. 2000. Feeding site selection by woodland caribou in north central British Columbia. Rangifer, Special Issue 12:159-172.

_ 2001. Foraging across a variable landscape: Behavioral decisions made by woodland caribou at multiple spatial scales. Oecologia 127:590-602.

KOJOLA, I., HELLE, T., NISKANEN, M., and AIKIO, P. 1995. Effects of lichen biomass on winter diet, body mass and reproduction of semi-domesticated reindeer Rangifert.tarandus in Finland. Wildlife Biology 1:33-38.

KUMPULA, J. 2001. Winter grazing of reindeer in woodland lichen pasture: Effect of lichen availability on the condition of reindeer. Small Ruminant Research 39:121-130.
KUMPULA, J., COLPAERT, A., and NIEMINEN, M., 2000. Condition, potential recovery rate, and productivity of lichen (Cladonia spp.) ranges in the Finnish Reindeer Management Area. Arctic 53(2):152-160.

LARTER, N.C., and NAGY, J.A. 2001. Variation between snow conditions at Peary caribou and muskox feeding sites and elsewhere in foraging habitats on Banks Island in the Canadian High Arctic. Arctic and Alpine Research 33(2):123-130.

McEWAN, E.H., and WHITEHEAD, P.E. 1970. Seasonal changes in the energy and nitrogen intake in reindeer and caribou. Canadian Journal of Zoology 48:905-913.

MILLER, D.R. 1974. Seasonal changes in the feeding behaviour of barren-ground caribou on the taiga winter range. In: Geist, V., and Walther, F. eds. The behaviour of ungulates and its relation to management. IUCN New Series 24. Morges, Switzerland: IUCN.

NELLEMANN, C. 1996. Terrain selection by reindeer in late winter in central Norway. Arctic 49(4):339-347.

NIEMINEN, M., and HEISKARI, U. 1989. Diets of freely grazing and captive reindeer during summer and winter. Rangifer 9: $17-34$.

NIEMINEN, M., and PETERSSON, C.J. 1990. Growth and relationship of live weight to body measurements in semidomesticated reindeer (Rangifertarandus tarandus L.). Rangifer, Special Issue 3:353-361.

POOLE, K.G., HEARD, D.C., and MOWAT, G. 2000. Habitat use by woodland caribou near Takla Lake in central British Columbia. Canadian Journal of Zoology 78:1552-1561.

ROBY, D.D. 1978. Behavioural patterns of barren-ground caribou of the Central Arctic Herd adjacent to the Trans-Alaska oil pipeline. M.Sc. Thesis, University of Alaska Fairbanks.

- 1980. Winter activity of caribou of two arctic ranges. In: Reimers, E., Gaare, E., and Skjenneberg, S., eds. Proceedings of the Second International Reindeer/Caribou Symposium, 17-21 September 1979, Roros, Norway. Trondheim: Direktoratet for Vilt of Ferskvannsfisk. 537-544.

ROMINGER, E.M., ROBBINS, C.T., and EVANS, M.A. 1996. Winter foraging ecology of woodland caribou in northeastern Washington. Journal of Wildlife Management 60(4):719-728.

RUSSELL, D.E., and MARTELL, A.M. 1984. Winter range ecology of caribou (Rangifer tarandus). In: Olson, R., Hastings, R., and Geddes, F., eds. Northern ecology and resource management, Memorial essays honouring Don Gill. Edmonton: The University of Alberta Press. 117-144.

SALO, M.-L., TUORI, M., and KIISKINEN, T. 1982. Rehutaulukot ja ruokintanormit, märehtijät-siat-siipikarja-turkiseläimet (Feed tables and feeding norms, ruminants-swine-poultry-fur animals). In Finnish. Helsinki: Helsingin yliopiston monistuspalvelu. 70 p.

SCOTTER, G.W. 1967. The winter diet of barren-ground caribou in northern Canada. Canadian Field-Naturalist 81:33-39.

SKOGLAND, T. 1978. Characteristics of the snow cover and its relationship to wild mountain reindeer (Rangifer tarandus tarandus L.) feeding strategies. Arctic and Alpine Research 10(3):569-580.

THING, H. 1977. Behaviour, mechanics and energetics associated with winter cratering by caribou in northwestern Alaska. Biological Papers of the University of Alaska 18. 44 p. 